\title{
Una Hiwea, O Livro Vivo. Edited by Agostinho Manduca M. Ĩka Muru. 2012. Literaterras and Faculdade de Letras da Universidade Federal de Minas Gerais, Belo Horizonte. 284 pp. - and - Una Shubu Hiwea: Livro Escola Viva do Povo Huni Kuĩ do Rio Jordão. 2017. Edited by Itaú Cultural. Itaú Cultural, São Paulo, and Dantes Editora, Rio de Janeiro. 76
} pp.

Thiago Serrano de Almeida Penedo ${ }^{1^{*}}$

${ }^{1}$ Escola Nacional de Botânica Tropical, Instituto de Pesquisas Jardim Botânico do Rio de Janeiro, Rio de Janeiro, Brasil. *serranoapenedo@gmail.com

Received August 16, 2021

OPEN $\curvearrowright$ ACCESS

Accepted October 28, 2021

Published January 29, 2022

DOI 10.14237/ebl.13.1.2022.1789

Copyright (c) 2022 by the author(s); licensee Society of Ethnobiology. This is an open-access article distributed under the terms of the Creative Commons Attribution-NonCommercial 4.0 International Public License (https://creativecommons.org/licenses/by-nc/4.0), which permits non-commercial use, distribution, and reproduction in any medium, provided the original author and source are credited.

In 2016, Coimbra published in this journal a very comprehensive review of the 2014 book Una Isĩ Kayawa: Livro de Cura do Povo Huni Kũ highlighting the importance of this work that describes the use of 109 medicinal plants by the Huni Kuĩ and traditional stories and texts about these medicinal plants and their cure process. The book was organised through the partnership among the Huni Kuĩ shamans and the botanist Alexandre Quinet, from the Rio de Janeiro Botanical Garden, with shaman Agostinho as the main organiser.

Before publishing this book, shaman Agostinho organised the book Una Hiwea-The Living Book, as the result of a partnership with the Languages Department from Federal University of Minas Gerais (UFMG). Many plant names, information on all kinds of illness that affect the Huni Kuĩ people from the Jordão River, and their traditional stories were recorded in this book. Four shamans organised a chapter each on their work with the medicinal plants.

In 2017, the book Una Shubu Hiwea-The Living Schoolbook was published. It covers the works of the Huni Kuĩ shamans from all villages in the Jordão municipality, Acre, Brazil. This is the same region from the former two books. All 36 villages along the Jordão and Tarauacá rivers were part of this project, through their shamans and students. This book compiles Huni Kuîs traditional stories and the description of the research about medicinal plants by each of the participating shamans.

These three books have many common features. They depict a process of cultural documentation of the Huni Kuĩ people living in Jordão, and they are all driven by older shamans. All the books have Huni Kuĩ authorship and are a result of the desire of the Huni Kuĩ to record their culture and medicinal plant knowledge for younger generations. The last point uniting these three books is the direct or indirect influence of the shaman Agostinho.

For a long time, Agostinho desired to record the traditional knowledge accumulated by him and the other elders, as he was afraid that this knowledge would be lost with his and the elder's deaths. His goal was to create a written record of their knowledge for the younger Huni Kuĩ generations (Coimbra Jr 2016). Although Agostinho passed away before the conclusion of the Una Isĩ Kayawa book, it did not stop the book from being published.

Recently, after the death of the Shaman Agostinho, the book Una Shubu Hiwea was published. Its main organiser was shaman Manoel Vandique Kaxinawa Dua Busa, who serves as the current 
coordinator of the Huni Kuĩ shamans from the Jordão river and was involved in the development of the other books. Through this publication we can see that Agostinho's dream lives on and it is shared mostly by the older shamans.

These texts offer invaluable teachings for people interested in the Amazonian peoples' cosmovision, specifically regarding the use of medicinal plants. These books also highlight another crucial pointthe Huni Kuĩ shaman are researchers and carry out their own research. They know and understand the surrounding biodiversity, classify it, and give it names. Regarding medicinal plants, they observe the patient's symptoms, test the plants, take notes in their notebooks, and use the plants again for validation. This is all in the books, especially Una Shubu Hiwea which presents how each shaman take their notes.

As stated by Vandebroek et al. (2011), knowledge is power, and for the Huni Kuĩ, the forementioned books shows that traditional knowledge is being used for local empowerment in benefit of the community. They are, in this manner, a rich source of knowledge and a good example that should be followed by academic researchers and professionals working in partnership with originary peoples or traditional communities.

\section{References Cited}

Coimbra, C. E. A. 2016. Una Isĩ Kayawa: Livro de Cura do Povo Huni Kuĩ do Rio Jordão. By Agostinho M. M. Ĩka Muru and Alexandre Quinet. 2014. Jardim Botânico do Rio de Janeiro and Dantes Editora, Rio de Janeiro. 260 pp. Ethnobiology Letters 7:24-25. DOI:10.14237/ebl.7.1.2016.561.

Vandebroek, I., V. Reyes-García, U. P. de Albuquerque, R. Bussmann, and A. Pieroni. 2011. Local Knowledge: Who Cares? Journal of Ethnobiology and Ethnomedicine 7:1-7. DOI:10.1186/1746-4269-735. 